\title{
RAP1 protein activates and silences transcription of mating-type genes in yeast
}

\author{
Stephen Kurtz and David Shore \\ Department of Microbiology, College of Physicians \& Surgeons, Columbia University, New York, New York 10032 USA
}

\begin{abstract}
RAP1 is a sequence-specific DNA-binding protein essential for cell growth. The occurrence of RAP1-binding sites in many promoter regions, the mating-type gene silencer elements, and telomeres suggests that RAP1 has multiple functions in the cell. To assess its role in transcription, temperature-sensitive mutations in RAP1 were generated. Analysis of $\operatorname{rap} 1^{\text {ts }}$ strains provides evidence that RAP1 functions in both transcriptional activation and silencing of mating-type genes. Several observations indicate that rap $1^{\text {ts }}$ strains are defective in the expression of MAT $\alpha$, whose upstream activation sequence (UAS) contains a RAP1-binding site. At

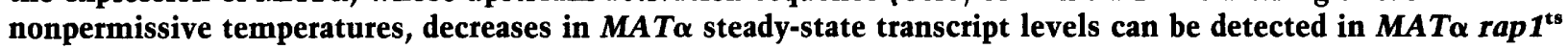
strains. Furthermore, these strains are deficient in $\alpha$-pheromone production and simultaneously express at least two $a$-specific genes. These phenotypes can be reversed by replacing the RAP1-binding site at MAT $\alpha$ with a binding site for the GAL4 transcriptional activator. Certain rap $1^{\text {ts }}$ alleles have an opposite effect on the silent mating-type locus $H M R$, which becomes partially derepressed at nonpermissive temperatures.
\end{abstract}

[Key Words: Saccharomyces cerevisiae; transcriptional activation; silencer; mating type; transcription factor]

Received October 19, 1990; revised version accepted February 1, 1991.

RAP1 (TUF/GRF1/TBA) has been independently identified as a sequence-specific DNA-binding protein in studies of ribosomal protein gene promoters (Huet et al. 1985 |, silencer elements at the nontranscribed matingtype loci $H M L$ and $H M R$ (Shore et al. 1987; Buchman et al. 1988a $)$, and the poly $\left(\mathrm{C}_{1-3} \mathrm{~A}\right)$ tracts at telomeres (Berman et al. 1986; Dunn 1989). The RAP1 protein has been purified, and its gene has been cloned and shown to be essential for growth (Shore and Nasmyth 1987). RAP1binding sites have since been identified in the promoters of a large number of genes in addition to those involved in translation, including many glycolytic enzyme genes and the MATa mating-type genes (for review, see Buchman et al. 1988b; Capieaux et al. 1989). The location of RAP1-binding sites at both upstream activation sequences (UASs) and silencers has led to the suggestion that RAP1 has a dual role in regulating transcription. Recent studies have demonstrated directly that RAP1 is also involved in controlling the length of $\operatorname{poly}\left(\mathrm{C}_{1-3} \mathrm{~A} \mid\right.$ tracts at telomeres (Lustig et al. 1990).

The idea that RAPl functions in vivo as an activator of transcription is supported by a number of deletion analyses of promoter regions containing RAP1-binding sites. Deletion of these sites from promoters typically results in a moderate reduction in expression (Rotenberg and Woolford 1986; Chambers et al. 1988; Elledge and Davis 1989; Hurd and Roberts 1989), although in some cases the effect appears to be more severe (Siliciano and Tatchell 1984; Nishizawa et al. 1989). Similarly, analyses of silencer elements has suggested a repressor function for
RAP1: Deletion of the RAP1-binding site at the $H M R$ silencer causes a partial derepression of this locus (Brand et al. 1987; Kimmerly et al. 1988). The function of RAP1 at a particular locus appears to depend on the context of its binding site within other regulatory sequences rather than the precise sequence of the site, and presumably results from interactions with other regulatory factors. So, for example, UAS-associated RAP1-binding-sites can substitute for the binding site normally found at the HMR silencer (Shore and Nasmyth 1987), and RAP1 binding sites taken from either UAS elements, silencers, or telomeres activate transcription when placed upstream of a TATA element (Buchman et al. 1988b).

The presence of RAP1-binding sites at both the MAT $\alpha$ promoter and the $H M L$ and $H M R$ silencers suggests that RAP1 might play a complex role in cell type determination. The MAT locus, which controls cell type /either a or $\alpha$ ), is situated near the centromere of chromosome III and can contain either the a or $\alpha$ allele. The MAT $\alpha$ allele encodes two regulatory proteins $(\alpha 1$ and $\alpha 2)$ that control the expression of a number of cell type-specific genes in haploids (e.g., pheromone and pheromone receptor genes). The MAT $\alpha 1$ protein is an activator of $\alpha$-specific genes, whereas MAT 2 is a repressor of the otherwise constitutive a-specific genes. Therefore, expression of both $\alpha 1$ and $\alpha 2$ represses a-specific genes and activates $\alpha$-specific genes, leading to the $\alpha$-mating phenotype. In the absence of $M A T \alpha$ expression cells display an a-mating phenotype. The MATa locus has no function in haploids but is required in a/ $\alpha$ diploids, which are nonmat- 
ing cells capable of sporulation. Two identical, yet nontranscribed, copies of mating-type genes are present near the telomeres of chromosome III, at loci called $H M R$ and $H M L$, which usually contain a and $\alpha$ alleles, respectively. Silencing of these loci is essential for mating. In haploid cells containing a wild-type $H O$ gene, the silent loci are used as donors of information in a mating-type switching event that results in a conversion of the allele present at the MAT locus (for review, see Nasmyth and Shore 1987; Herskowitz 1989).

Several studies have defined DNA sequence elements and genes necessary for maintaining transcriptional silencing. At $H M R$, a flanking sequence called $H M R E$ is required for repression of the locus (Abraham et al. 1984; Brand et al. 1985). The HMRE silencer is itself composed of three elements (called A, E, and B), one of which (element E) is a RAP1-binding site that is required for full repression (Brand et al. 1987; Shore and Nasmyth 1987; Kimmerly et al. 1988). Element A is an autonomous replicating sequence (ARS) consensus sequence, and element $B$ is a binding site for ARS-binding factor 1 (ABF1) (Shore et al. 1987; Buchman et al. 1988a; Diffley and Stillman 1988). Deletions of either A or B alone have no effect on silencing, but either element, in combination with the RAP1-binding site, provides complete repression in the context of $H M R E$. A number of unlinked trans-acting genes have been identified that are required for silencing. Mutations in the nonessential genes SIR2, $S I R 3$, or SIR4 result in a complete loss of silencer function (Rine and Herskowitz 1987), and mutations in SIR1 appear to affect the establishment, but not the maintenance, of the repressed state (Pillus and Rine 1989). In addition, deletions of the amino terminus of histone $\mathrm{H} 4$ lead to derepression of the silent loci (Kayne et al. 1988); and mutations in $N A T 1$ and $A R D 1$, components of an amino-terminal protein acetylase, result in a partial loss of silencing (Whiteway et al. 1987; Mullen et al. 1989). No mutations in the genes encoding the known silencer binding proteins RAP1 and ABF1 have been isolated previously in screens for silencing mutants (Miller and Nasmyth 1984; Rine and Herskowitz 1987), perhaps because their functions are redundant at the silencers and both are essential genes.

To investigate the role of RAPl in transcriptional regulation, we have isolated conditionally lethal mutations in the RAP1 gene. Strains containing these mutations were then used to examine the requirement for RAP1 in gene expression at MAT $\alpha$ and repression at $H M R$. These experiments provide genetic evidence that RAP1 has a fundamental role in transcriptional activation and repression and demonstrate the importance of RAP1 in establishing and maintaining cell type in yeast.

\section{Results}

\section{Isolation and initial characterization of $\operatorname{rap}^{\text {ts }}$ mutants}

Temperature-sensitive mutations in RAP1 were generated by mutagenesis of the cloned gene. Because the $R A P 1$ gene is essential, we used a plasmid shuffle tech- nique (Boeke et al. 1987; Mann et al. 1987) to introduce a mutagenized copy of the gene into cells deleted for the chromosomal copy. Four independent temperature-sensitive mutants were obtained using this procedure. Plasmids recovered from these strains conferred a temperature-sensitive phenotype upon retransformation of the original strain and subsequent plasmid shuffling, confirming that the temperature-sensitive mutations were plasmid encoded. The mutant alleles were isolated from these plasmids, subcloned into an integrating vector, and used to replace the RAP1 locus. All of the mutations are recessive; they are complemented by plasmids containing the wild-type $R A P 1$ gene, and heterozygous diploids grow normally at $37^{\circ} \mathrm{C}$. The integrated alleles segregate as expected $\left(2+: 2-\right.$ for growth at $\left.37^{\circ} \mathrm{C}\right)$ in crosses to a wild-type strain. Strains containing these rap $1^{\text {ts }}$ alleles at the genomic RAP1 locus were used in all experiments presented below.

The effect on cell growth of the four rap $1^{\text {ts }}$ alleles was assessed at permissive $\left(25^{\circ} \mathrm{C}\right)$ and restrictive $\left(37^{\circ} \mathrm{C}\right)$ temperatures. As shown in Figure 1A, the mutants display a range of different growth phenotypes relative to the wildtype strain. At $25^{\circ} \mathrm{C}$, strains containing the rap1-2 or the rap 1-5 mutation grow at near wild-type rates $(2 \mathrm{hr}$ doubling time). At $37^{\circ} \mathrm{C}$, these strains gradually arrest their growth after 3 to 4 doublings. Strains containing either the rap1-1 or rap1-4 mutation have a more dramatic growth phenotype. At $25^{\circ} \mathrm{C}$, both of these strains have a pronounced increase in doubling time $/ 4 \mathrm{hr}$ for rap 1-1 and $7 \mathrm{hr}$ for rap1-4) and arrest growth after 1 to 2 doublings when shifted to $37^{\circ} \mathrm{C}$. The relative growth differences among the four mutant strains is reflected in their efficiency of plating after a shift to $37^{\circ} \mathrm{C}$. The strains that grow poorly at $25^{\circ} \mathrm{C}$ lose viability at the restrictive temperature more rapidly than the strains that grow normally at $25^{\circ} \mathrm{C}$. Strains carrying the rap1-2 or rap1-5 mutations show only a twofold decrease in viability for every $4 \mathrm{hr}$ of incubation at $37^{\circ} \mathrm{C}$, whereas the rap 1-1 and rap1-4 strains show a more dramatic loss of viability $\left\{\sim 10\right.$-fold reduction for every $4 \mathrm{hr}$ at $37^{\circ} \mathrm{C}$; Fig. 1B). In contrast, wild-type cells show no detectable loss of viability after similar periods of incubation at $37^{\circ} \mathrm{C}$.

None of the rap $1^{\text {ts }}$ mutants appear to arrest growth at a particular stage in the cell cycle. Strains containing rap $1^{\text {ts }}$ mutations have a larger cell size than wild-type cells even at permissive growth conditions. Many of the cells in a population carrying a rap $^{t s}$ mutation have pronounced vacuoles and grossly altered morphologies relative to wild-type cells after a temperature shift to $37^{\circ} \mathrm{C}$ (data not shown).

On the basis of relative differences in growth between the four temperature-sensitive mutations, it seemed likely that each mutant represented a unique rap1 allele. We mapped the mutations to regions in the RAP1 gene by a series of restriction fragment swap experiments (see Materials and methods|. Appropriate mutant fragments were then subcloned and sequenced. The four mutants are unique missense mutations in the $R A P 1$-coding sequence distributed over a region of $\sim 250$ amino acids in the middle of the coding sequence (Fig. 2). 
A

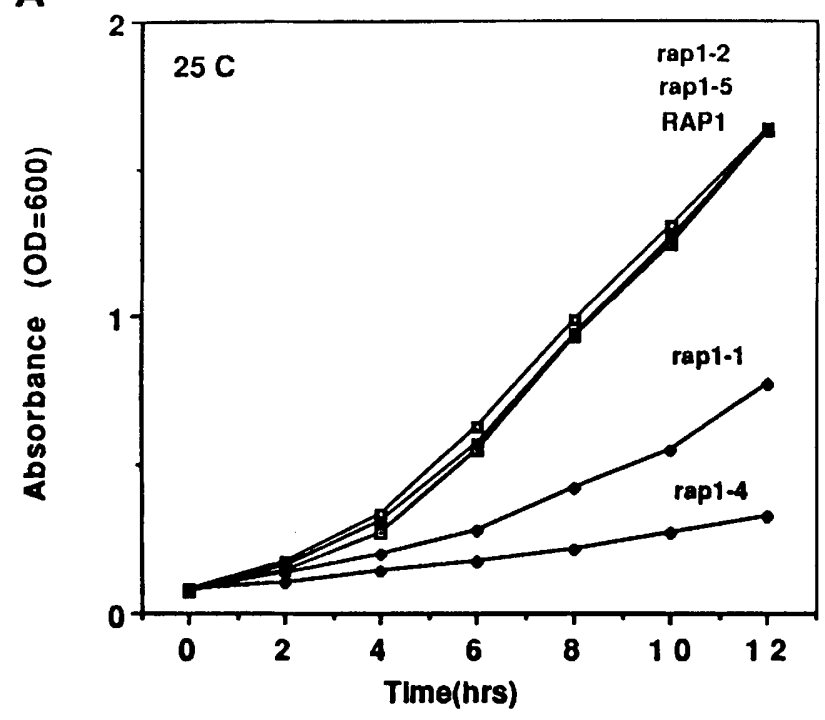

B

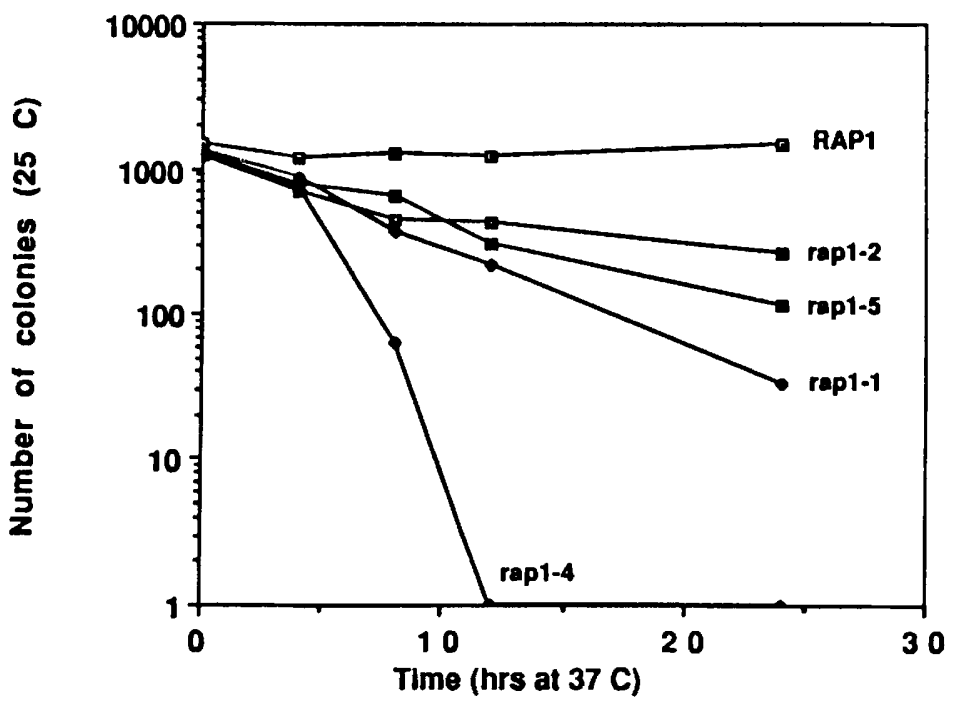

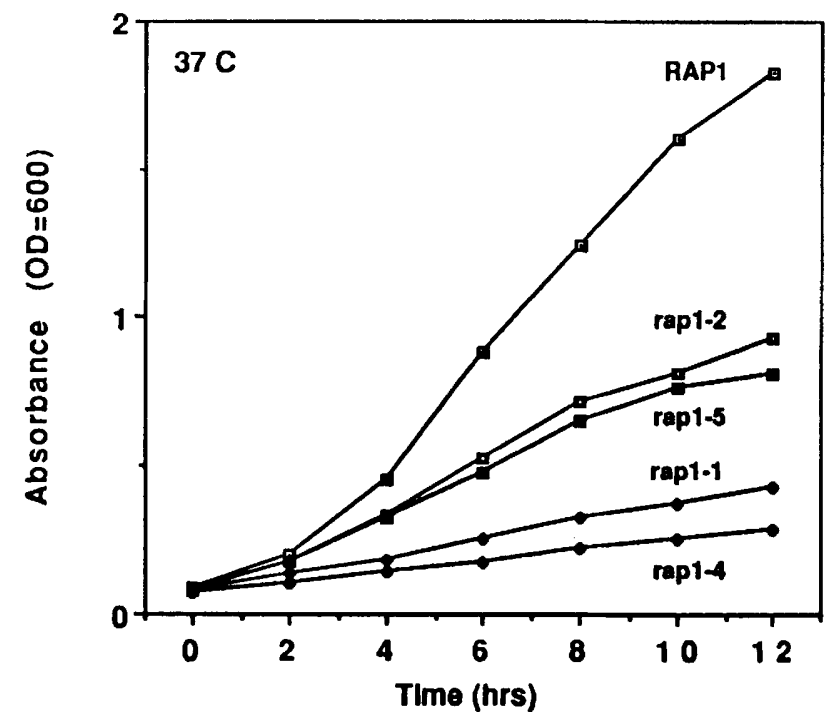

Figure 1. Growth phenotypes of rap ts mutants at $25^{\circ} \mathrm{C}$ and $37^{\circ} \mathrm{C}$. (A) Log-phase cultures of wild-type (YDS3) and rap $1^{\text {ts }}$ strains (YDS406, 409, 410, 413) were split and maintained in YEPD media at $25^{\circ} \mathrm{C}$ or shifted to $37^{\circ} \mathrm{C}$. Aliquots were removed at regular intervals, and the optical density at $600 \mathrm{~nm}$ was determined. $O_{600}$ values are plotted vs. time of incubation. (B) Survival of rap $1^{\text {ts }} \mathrm{mu}-$ tants after incubation at the restrictive temperature. Logphase cultures of wild-type (YDS3) and rap $1^{\text {ts }}$ strains (YDS406, 409, 410, 413) were shifted from $25^{\circ} \mathrm{C}$ to $37^{\circ} \mathrm{C}$. At various intervals, equal $\mathrm{OD}_{600}$ units were diluted, spread on YEPD plates, and incubated at $25^{\circ} \mathrm{C}$. After 5 days, the number of surviving colonies was determined and plotted vs. time of incubation at $37^{\circ} \mathrm{C}$.
$R A P 1$ is required for the proper regulation of genes controlled by the MAT $\alpha$ locus

In constructing strains for the purpose of isolating rap1 mutants we noticed an unusual property of $M A T \alpha$ cells carrying both a deletion of the genomic RAP1 locus and a plasmid containing the wild-type RAP1 gene. In patch mating assays, a portion of these cells were capable of mating to MAT $\alpha$ testers, whereas otherwise isogenic strains containing the MATa allele mated normally (Fig. 3). A quantitative mating analysis indicated that the $M A T \alpha$, rap1 deletion strains mate with the inappropriate

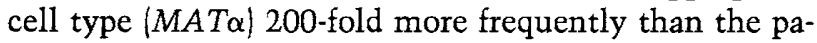
rental wild-type $M A T \alpha$ strain (Table 1). We were able to show by a simple genetic test that this aberrant mating behavior occurred only in cells that had lost the RAP1 plasmid; selection for the URA3 gene on this plasmid abolished the ability of this strain to form diploids with the MAT $\alpha$ tester strain. This result suggested that loss of the RAP1-containing plasmid was a prerequisite for alike mating, an event that rescues these cells from death. Because RAP1 binds in vitro to the MAT $\alpha$ UAS (Shore and Nasmyth 1987; Buchman et al. 1988a), we suspected that a reduction in RAPl activity in cells that have lost the RAP1 plasmid might directly affect transcription of the $M A T \alpha$ locus. Previous studies have shown that the absence of functional MAT $\alpha$ gene products, either due to mutations in both $\alpha 1$ and $\alpha 2$ or promoter deletions that abolish $M A T \alpha$ transcription, results in an a-mating phenotype (Strathern et al. 1981; Tatchell et al. 1981; Siliciano and Tatchell 1984).

To test whether RAP1 is required for the expression of the $M A T \alpha$ locus, we measured the activities of several gene products known to be directly regulated by $M A T \alpha$. 


\section{RAP 1}

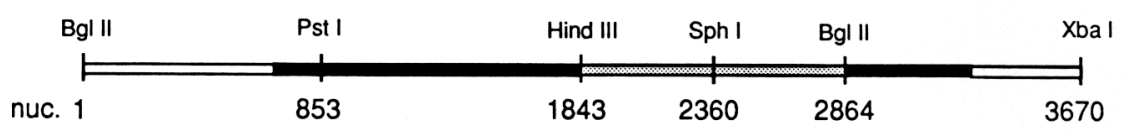

\begin{tabular}{|c|c|c|}
\hline ts allele & $\begin{array}{l}\text { nucleotide } \\
\text { change }\end{array}$ & $\begin{array}{l}\text { amino acid } \\
\text { change }\end{array}$ \\
\hline $\operatorname{rap} 1-1$ & 2451: G->C & $\mathrm{ALA}^{563} \rightarrow \mathrm{PRO}$ \\
\hline rap $1-2$ & 2136: G->A & ALA $^{458} \rightarrow$ THR \\
\hline rap 1-4 & 1863: G->A & $\mathrm{GLU}^{367} \rightarrow>$ LYS \\
\hline $\operatorname{rap} 1-5$ & 2845: C->T & $\mathrm{PRO}^{694} \rightarrow \mathrm{LEU}$ \\
\hline
\end{tabular}

Figure 2. Allele map of rap ${ }^{t s}$ mutations. rapl $^{t s}$ mutations were mapped and sequenced as described in Materials and methods. The nucleotide and amino acid changes are listed for each allele. The line drawing, representing the RAP1 gene, indicates the positions of restriction sites used in mapping, the RAP1-coding region (solid bar), and the region containing the temperature-sensitive mutations (stippled bar).
The $\alpha 1$ and $\alpha 2$ proteins regulate genes encoding both $\alpha$ and a-specific functions (Nasmyth and Shore 1987; Herskowitz 1989): the $\alpha 1$ protein is an activator of $\alpha$-specific genes, such as $M F \alpha 1$ and $M F \alpha 2$, which encode $\alpha$-factor, whereas $\alpha 2$ is a repressor of a-specific genes, including the genes that encode a-factor and barrier, a protease that inactivates $\alpha$-factor. The presence or absence of the mating factors and the barrier protease, which are all readily detectable in a bioassay, provides a sensitive measure of $\alpha 1$ and $\alpha 2$ activities.

rap $1^{\text {ts }}$ strains were tested for the synthesis of $\alpha$-factor using a halo assay (Julius et al. 1983) in which the production of $\alpha$-factor by a patch of MAT $\alpha$ cells is measured

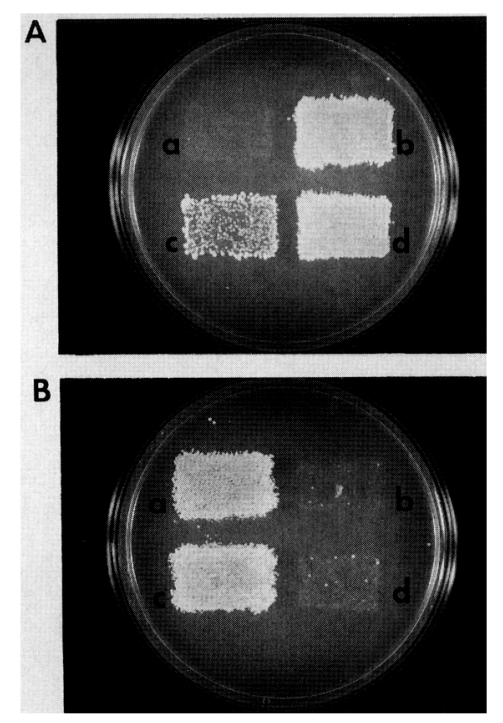

Figure 3. rap1 deletion strains mate inappropriately. Patches of wild-type and rap1 deletion strains were printed onto minimal plates spread with a lawn of MAT $\alpha$ tester strain YDS32 $(A)$ or MATa tester strain YDS31 $(B)$. Plates were incubated at $30^{\circ} \mathrm{C}$ for 2 days. (a) MATa (YDS3); (b) MATa (YDS2); (c) MATa, rap1 :: leu2 (YDS203-2d); (d) MATa, rap1 :: leu2 (YDS203-6b). Strains 203-2d and 203-6b contain a CEN plasmid bearing a wild-type $R A P 1$ gene. as a zone of growth inhibition in a surrounding lawn of $M A T a$ cells. All four MAT $\alpha$ rap $1^{\text {ts }}$ strains produce halos typical of $M A T \alpha$ cells at the permissive temperature $\left(25^{\circ} \mathrm{C}\right)$. However, at semipermissive temperatures $\left(30-33^{\circ} \mathrm{C}\right)$ these strains fail to produce $\alpha$-factor halos (Fig. 4 ; data presented is for the rap1-1 allele). The severity of this phenotype correlates with the overall growth rates of the different rap $1^{\text {ts }}$ alleles: rap1-1 and rap1-4 fail to produce halos when transferred directly from $25^{\circ} \mathrm{C}$ to $30^{\circ} \mathrm{C}$ tester plates, whereas the rap1-2 or rap 1-5 alleles require a $6-\mathrm{hr}$ preincubation at $33^{\circ} \mathrm{C}$ before the loss of $\alpha$-factor activity is evident. Because the $\alpha$-factor genes require $\alpha 1$ protein for expression, this observation is consistent with the notion that rap $1^{\text {ts }}$ strains are defective in the expression of MATa1. In the experiments described below we show that the failure to produce $\alpha$-factor halos in rap $1^{\text {ts }}$ strains is not an indirect effect arising from diminished growth rate or cell viability at elevated temperatures but, rather, is due to a specific defect in transcriptional activation of $M A T \alpha$.

Coincident with the decrease in $\alpha$-factor production in the $M A T \alpha$ rap $1^{\text {ts }}$ strains is the inappropriate expression of several a-specific genes. At semipermissive temperatures, MAT $\alpha$ rap $1^{\text {ts }}$ strains express a-factor, a peptide normally secreted by MATa strains and detectable in a halo assay (Fig. 5A; rap1-1 allele is shown). Because afactor gene expression is repressed in MAT $\alpha$ cells by the $\alpha 2$ protein (Brake et al. 1985; Johnson and Herskowitz 1985), this observation suggests that rap $1^{\text {ts }}$ strains are also defective in the expression of $\alpha 2$. Consistent with

Table 1. Relative mating efficiencies of wild-type and rap1 deletion strains

\begin{tabular}{lcll}
\hline & Mating & \multicolumn{2}{c}{ Efficiency of mating } \\
\cline { 3 - 4 } Strain & type & x MAT a & $x$ MAT $\alpha$ \\
\hline YDS 3 & $\alpha$ & 0.48 & $1.2 \times 10^{-6}$ \\
YDS 203-2d & $\alpha$ & 0.56 & $2.6 \times 10^{-4}$ \\
YDS 2 & $\mathbf{a}$ & $1 \times 10^{-6}$ & 0.7 \\
YDS 203-6b & $\mathbf{a}$ & $1 \times 10^{-6}$ & 0.83 \\
\hline
\end{tabular}



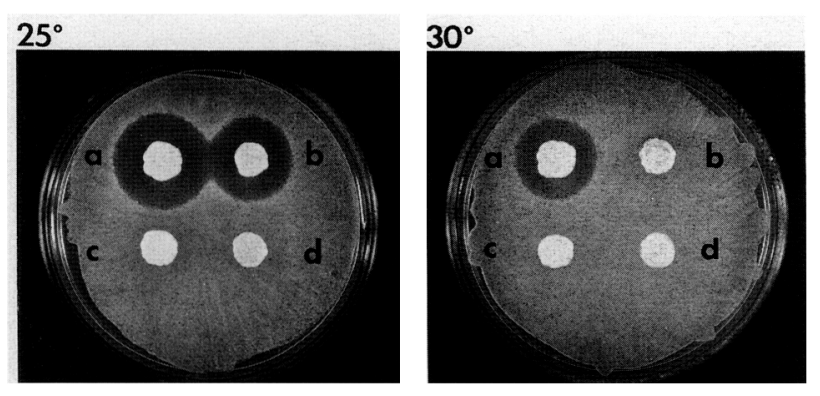

Figure 4. rap $^{t s}$ strains are defective in $\alpha$-Factor production at elevated temperatures. $\alpha$-Factor production was measured using a halo assay at $25^{\circ} \mathrm{C}$ (permissive) and $30^{\circ} \mathrm{C}$ (semirestrictive). Fresh colonies of each strain were toothpicked onto plates spread with a lawn of strain RC634 (MATa sst1-3) and incubated at the designated temperature for 2 days. (a) Wild-type RAP1, $M A T \alpha$ (YDS3); (b) rap1-1, MATa (YDS406); (c) wild-type RAP1, MATa (YDS2); (d) rap1-1, MATa (YDS407).

this idea, we found that another a-specific gene, BAR1/ SST1, which encodes barrier and is also repressed by $\alpha 2$ (Chan 1977; Sprague and Herskowitz 1981), is expressed in the MAT $\alpha$ rap $1^{t s}$ strains at semipermissive temperatures. Barrier production was measured by patching the $M A T \alpha$ rap $1^{\text {ts }}$ strains next to a wild-type MATa strain on a lawn of MATa sst1 cells (Fig. 5B). The growth of the lawn is inhibited by $\alpha$-factor secreted from the streak of $M A T \alpha$ wild-type cells. At $25^{\circ} \mathrm{C}$, the $M A T \alpha$ rap $1^{\text {ts }}$ strains secrete $\alpha$-factor, and consequently the lawn does not overcome this growth inhibition. Yet at $30^{\circ} \mathrm{C}$, the patch of $M A T \alpha$ rap $1^{\text {ts }}$ cells protected the lawn from growth inhibition, indicating that the $\operatorname{rap} 1^{t s}$ strains produce barrier at the elevated temperature. A MATa strain, which produces barrier constitutively, protected the lawn at both temperatures. In addition to suggesting a defect in $\alpha 2$ activity, these experiments show that although $M A T \alpha$ rap $1^{\text {ts }}$ strains are unable to produce an $\alpha$-factor halo, they are still capable of expressing and secreting other gene products (a-factor and barrier) at semipermissive temperatures. These phenotypes are observed in strains containing any of the four rap $1^{\text {ts }}$ alleles after a shift to semipermissive temperatures (data not shown).

Because the aberrant production of barrier in the MAT $\alpha$ rap $1^{t s}$ strains could also account for the loss of $\alpha$-factor activity at semipermissive temperatures, we examined the production of $\alpha$-factor in these strains in the absence of the BAR1 gene. MATa, rap $1^{\text {ts }}$, bar ::LEU2 strains produce near wild-type levels of $\alpha$-factor at $25^{\circ} \mathrm{C}$; however, at $30^{\circ} \mathrm{C}$, these strains produce little or no detectable $\alpha$-factor (Fig. 6A). Therefore, the aberrant production of barrier in the MAT $\alpha$ rap $1^{\text {ts }}$ strains cannot alone account for their reduced $\alpha$-factor production. This result further supports the conclusion that expression of $\alpha 1$, the activator of the $\alpha$-factor genes, is also reduced in the rap $1^{t s}$ strains following a temperature shift. Finally, the $M A T \alpha$-specific phenotypes of the rap $1^{t s}$ mutants do not result from a derepression of the silent $H M R$ a locus, as they are observed in strains carrying a deletion of the a1 and a2 genes at $H M R$ (data not shown).
Steady-state levels of transcripts from $M A T \alpha$ and from the $\alpha 1$-regulated gene encoding $\alpha$-factor $(M F \alpha 1)$ were measured in rap $1^{\text {ts }}$ strains following a shift to nonpermissive conditions. These RNAs were analyzed on Northern blots. A probe specific for URA3, a gene that does not have a RAP1-binding site in its regulatory region, was included as an internal control. There is a temperature-dependent decrease in the amounts of $M A T \alpha 1$ and $M A T \alpha 2$ mRNAs in strains containing the rap1-1 (Fig. 7A) or rap1-4 allele (data not shown) over the course of an $18-\mathrm{hr}$ incubation at $33^{\circ} \mathrm{C}$. We note that the decrease in the levels of MAT 1 and MAT 22 messages is not always as apparent in these strains and is difficult to detect in strains containing either the rap1-2 or rap1-5 alleles (data not shown). The behavior of strains with the rap1-2 and rap 1-5 alleles is consistent with properties described above, indicating that they are weak alleles; these strains are defective in $\alpha$-factor production and aberrantly produce a-factor and barrier only after a preincubation at nonpermissive temperatures.

We also note that the amount of $M F \alpha 1$ message drops significantly following temperature shift (Fig. 7A, $M F \alpha 1$, and this decrease is apparent before there is a detectable drop in MAT $\alpha 1$ transcript levels. This may indicate that $M F \alpha 1$ transcription is extremely sensitive to small fluctuations in levels of $M A T \alpha 1 \mathrm{mRNA}$, the
A

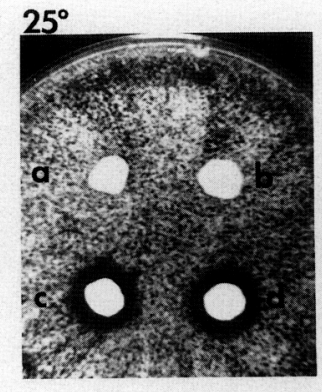

B

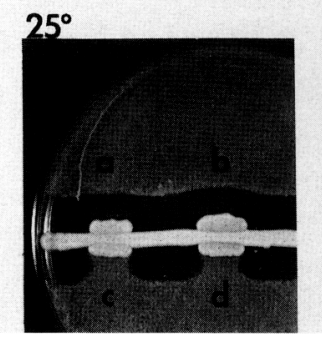

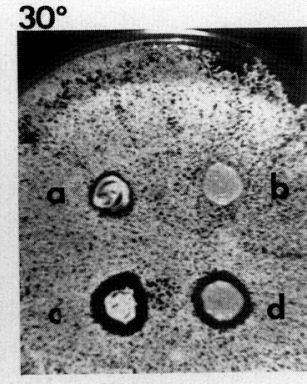

$30^{\circ}$

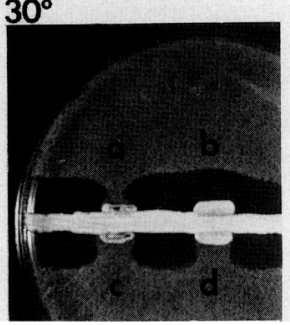

Figure 5. $\mathrm{rap}^{\text {ts }}$ strains express a-specific genes at elevated temperatures. $(A)$ a-Factor halo assay at $25^{\circ} \mathrm{C}$ and $30^{\circ} \mathrm{C}$ on plates spread with a lawn of strain XBH8-2c (MAT $\alpha$ sst2-4). (a) rap1-1, $M A T \alpha$ (YDS406); (b) wild-type RAP1, MATa (YDS3); (c) rap1-1, MATa (YDS407); (d) wild-type RAP1, MATa (YDS2). (B) Barrier assay at $25^{\circ} \mathrm{C}$ and $30^{\circ} \mathrm{C}$ on plates spread with a lawn of strain RC634 (MATa, sst1-3). Strains were patched alongside the streak of MAT $\alpha$ cells that continues across the plate. (a) rap1-1, $M A T \alpha$ (YDS406); (b) wild-type RAP1, MATa (YDS3); (c) rap1-1, $M A T \mathbf{a}$ (YDS407); (d) wild-type RAP1, MATa (YDS2). 
A
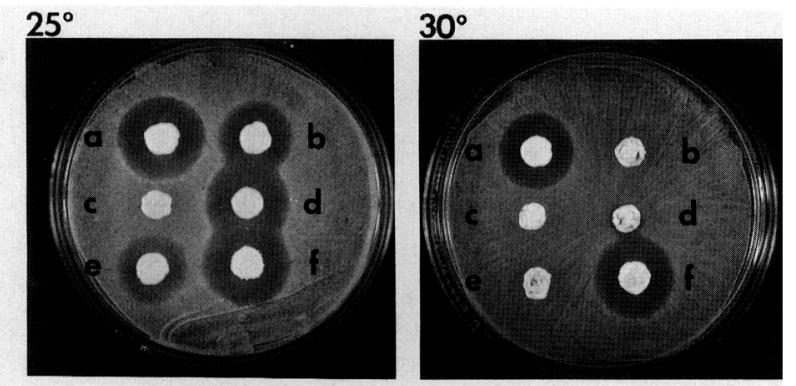

B
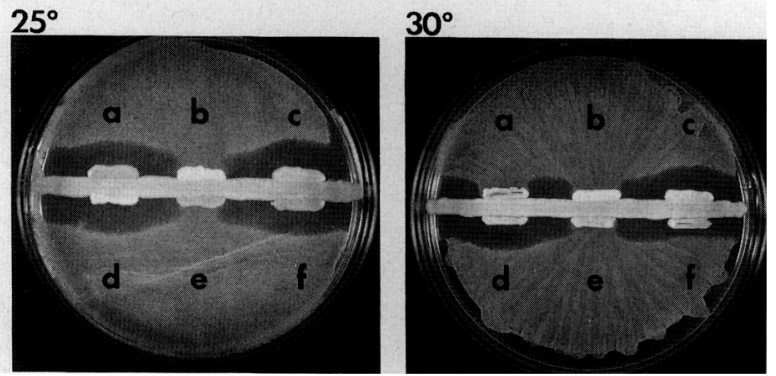

Figure 6. A heterologous promoter restores the activation defect in rap $^{t s}$ strains. $(A) \alpha$-Factor halo assay at $25^{\circ} \mathrm{C}$ and $30^{\circ} \mathrm{C}$ on plates spread with a lawn of strain RC634 (MATa, sst1-3). (a)

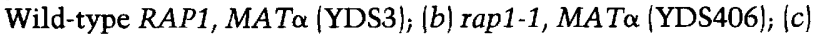
rap1-1, MATa (YDS407); (d) rap1-1, MATa, bar :: LEU2 (YDS540); (e) rap1-1, UAS $\mathrm{Gal}_{-}-\mathrm{MAT} \alpha, \mathrm{GAL}^{+}{ }^{+}$(YDS558); (f) rap1-1, $\mathrm{UAS}_{\mathrm{Gal}}-\mathrm{MAT} \alpha, \Delta$ gal80 (YDS447). (B) Barrier assay at $25^{\circ} \mathrm{C}$ and $30^{\circ} \mathrm{C}$ on plates spread with a lawn of strain RC634. (a) rap1-1, MATa (YDS406); (b) wild-type RAP1, MATa (YDS2); $(c)$ wild-type RAP1, MAT $\alpha$ (YDS3); (d) rap1-1, $\mathrm{UAS}_{\mathrm{Ga}}-M A T \alpha$,

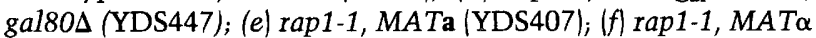
bar1 :: LEU2 (YDS540).

MAT 1 mRNA produced after temperature shift is nonfunctional, or RAP1 directly affects transcription of $M F \alpha 1$ (see Discussion). We therefore devised another experiment, described below, to assess the affect of the rap $1^{t s}$ mutations on $M A T \alpha$ transcription.

\section{A heterologous promoter at MAT $\alpha$ restores $\alpha$-specific functions in rap ${ }^{\text {ts }}$ strains}

Because a known RAP1-binding site has been shown by deletion analysis to be an essential element in the $M A T \alpha$ UAS and because mutations in this binding site lead to mating-specific phenotypes very similar to those observed in the rap $1^{\text {ts }}$ mutants (Giesman et al. 1991), a different experiment was designed to test whether $M A T \alpha$ transcription is defective in the rap $1^{\text {ts }}$ strains. We reasoned that if the mating-specific phenotypes of the rap $1^{\text {ts }}$ mutants were due to an inability to properly transcribe the MAT $\alpha$ genes, then replacing the MAT $\alpha$ UAS (RAP1-binding site) with a heterologous UAS element should abolish these phenotypes and restore the $\alpha$-cell characteristics.

We therefore replaced the RAPl-binding site in the
MAT $\alpha$ promoter with a single binding site for the GAL4 transcriptional activator (see Materials and methods). This $\mathrm{UAS}_{\mathrm{Gal}}-M A T \alpha$ construct was inserted at the MAT locus in a strain that contained the rap1-1 mutation and a gal80 gene deletion. The gal80 mutation was used to facilitate the analysis of the $\mathrm{UAS}_{\mathrm{Gal}}-M A T \alpha$ fusion. Because the product of the GAL80 gene is a negative regulator of GAL4 activity in glucose-grown cells (Johnston et al. 1987; Lue et al. 1987; Ma and Ptashne 1987), deletion of this gene should result in constitutive (galactoseindependent) expression from $\mathrm{UAS}_{\mathrm{Gal}}-M A T \alpha$, allowing us to perform halo assays under optimal growth conditions.

rap ${ }^{t s}$ strains containing the $\mathrm{UAS}_{\mathrm{Gal}}-M A T \alpha$ gene and the gal80 mutation produce wild-type levels of $\alpha$-factor at all temperatures (Fig. 6A, strain f) and no longer produce barrier (Fig. 6B, strain d) or a-factor (data not shown) at the elevated temperatures, indicating that the $M A T \alpha$-regulated functions have been restored. The restoration of $\alpha$-specific functions is not the consequence of overexpression from the heterologous $\mathrm{UAS}_{\mathrm{Gal}}-M A T \alpha$ promoter because Northern blot analysis indicates that transcript levels produced from the hybrid gene are similar to those produced from the wild-type promoter (Fig. 7B). These results suggest that the mating-specific phenotypes associated with the rap $1^{t s}$ mutations are due to an inability to properly transcribe the $M A T \alpha$ genes, and we conclude from this that one function of the wild-type RAP1 protein is to activate transcription at MAT $\alpha$.

\section{rap $1^{\text {ts }}$ alleles affect transcriptional silencing at HMR}

Deletion of the RAPl-binding site in the $H M R$ silencer results in a partial derepression of the locus (Brand et al. 1987; Kimmerly et al. 1988). To determine whether the rap ${ }^{t s}$ alleles affect silencing, we measured the transcrip-

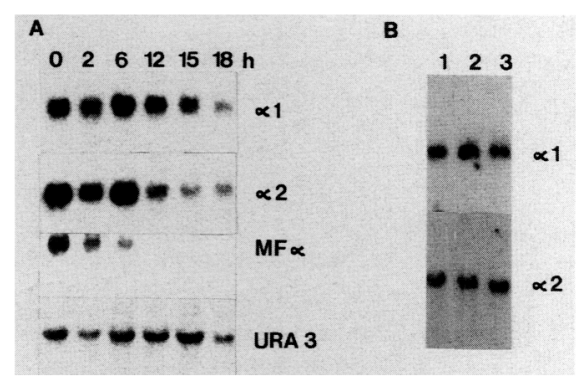

Figure 7. rap1-1 mutants are defective in MAT $\alpha$ transcription. (A) Northern blot analysis of $M A T \alpha$, rap1-1 strain YDS406. RNAs were isolated from a continuous culture at $0,2,6,12,15$, and $18 \mathrm{hr}$ following a temperature shift from $25^{\circ} \mathrm{C}$ to $33^{\circ} \mathrm{C}$. The filter was hybridized successively with probes for the $\alpha 1, \alpha 2$, $\alpha$-factor $(M F \alpha 1)$, and URA3 transcripts. $(B)$ Northern blot analysis of $M A T \alpha$ transcripts from the $\mathrm{UAS}_{\mathrm{Ga}}-M A T \alpha$ construct. RNAs were isolated from YDS439; MAT $\alpha$, rap1-1, $\Delta$ gal80

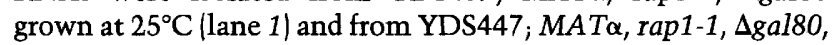
$\mathrm{UAS}_{\mathrm{Ga}}-M A T \alpha$ grown at $25^{\circ} \mathrm{C}$ (lane 2) and $8 \mathrm{hr}$ after a shift to $33^{\circ} \mathrm{C}$ (lane 3). The filter was hybridized successively with probes for the $\alpha 1$ and $\alpha 2$ transcripts. 
tion of HMRa1 after a temperature shift. Because the $H M R$ silencer is only partially dependent on the RAP1binding site (element $\mathrm{E}$ ), we also measured $H M R \mathbf{a} 1$ transcription in strains carrying deletions of either of the two other silencer regulatory elements, $A$ and $B$. Both the $h m r \Delta A$ and $h m r \Delta B$ silencers are totally functional, but unlike the wild-type silencer they are dependent on the RAP1-binding site for repression (Brand et al. 1987). Therefore, we expected that any effect on silencing in the rap $1^{\text {ts }}$ strains would be more pronounced in the $h m r \Delta A$ or $h m r \Delta B$ silencer backgrounds.

RNAs were prepared from strains containing both the $r a p^{t s}$ alleles and either a wild-type, $h m r \Delta A$, or $h m r \Delta B$ silencer after a shift from $25^{\circ} \mathrm{C}$ to $37^{\circ} \mathrm{C}$. The steady-state level of the $H M R \mathbf{a} 1$ transcript was quantified by an S1 nuclease protection assay, using the $S I R 3$ transcript as an internal control (Miller 1984). In strains containing the rap1-5 allele, this analysis detected a1 transcripts 4 $\mathrm{hr}$ after the temperature shift in a strain containing the $h m r \Delta A$ silencer and $8 \mathrm{hr}$ after the shift in a strain containing the $h m r \Delta B$ silencer (Fig. 8). Derepression of $H M R$ was also detected in a strain containing the rap1-4 allele and a $h m r \Delta A$ silencer but not in strains containing the rap1-1 or rap1-2 alleles (data not shown). No derepression of $H M R$ was detected in strains containing a rap ${ }^{t s}$ allele and a wild-type silencer (A, E, and B present). Because a deletion of the RAP1-binding site $(h m r \Delta E)$ only partially derepresses $H M R(\sim 10 \%)$, it may be the case that cell death precludes detection of expression at $H M R$ in rap ${ }^{t s}$ strains containing a wild-type silencer. Derepression of $H M R$ in strains carrying the rap1-5 allele is the

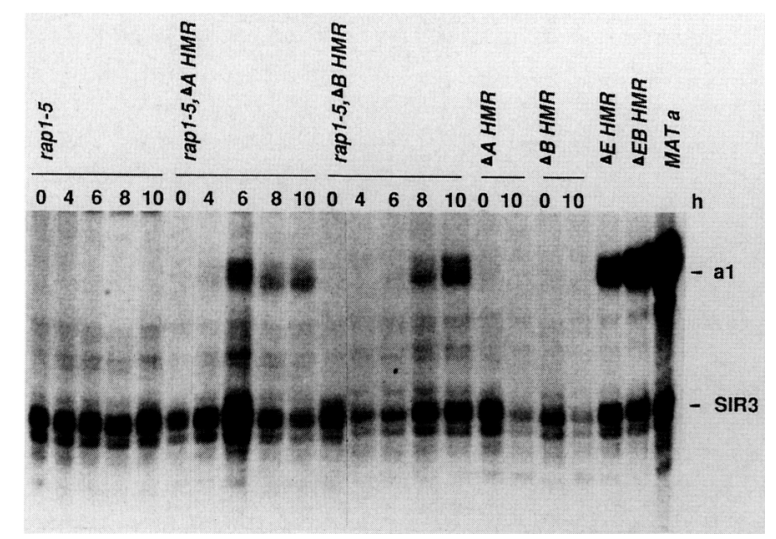

Figure 8. rap1-5 mutants are defective in silencing $H M R$ at elevated temperatures. $\$ 1$ nuclease mapping of transcripts produced from HMRa1 in MATa strains containing rap1-5 (YDS410), rap1-5 and an $h m r \Delta A$ silencer (YDS550), and rap1-5 and an $h m r \Delta B$ silencer (YDS551). RNAs were extracted from aliquots of continuous cultures at various times after a shift from $25^{\circ} \mathrm{C}$ to $37^{\circ} \mathrm{C}$. RNAs were also prepared from wild-type $R A P 1, M A T \alpha$ strains with partial silencer deletions $[h m r \Delta A$ (YDS36), hmr $\Delta B$ (YDS37)] that do not produce al at any temperature (lanes $0 \mathrm{hr}$ and $10 \mathrm{hr}, \mathrm{hmr} \Delta A$; lanes $0 \mathrm{hr}$ and $10 \mathrm{hr}$, $h m r \Delta B \mid$ and from strains that produce al transcripts irrespective of temperature [ $h m r \Delta E$ (YDS39), hmr $\Delta E B$ (YDS338), MATa (YDS2)]. Lane designations indicate hours after the shift to $37^{\circ} \mathrm{C}$. consequence of temperature elevation on this allele; no derepression of these silencer constructions occurs in wild-type RAP1 strains at any temperature (see Fig. 8).

\section{DNA-binding activity is heat labile in rap ${ }^{\text {ts }}$ strains}

All of our rap $1^{\text {ts }}$ mutants map within or close to a large region in the middle of the protein (from approximately amino acid 360 to 600) that appears to be required for sequence-specific DNA binding (Henry et al. 1990; D. Balderes and D. Shore, unpubl.). To determine whether the various $\mathrm{rap}^{t s}$ alleles affected the DNA-binding activity of the mutant proteins, cell extracts were prepared from each of the four temperature-sensitive strains before and after a shift to the restrictive temperature. Strains were maintained in culture at $37^{\circ} \mathrm{C}$ for $12 \mathrm{hr}$, and aliquots were removed every $2 \mathrm{hr}$ for preparation of cell extracts. Gel mobility-shift assays were performed at $20^{\circ} \mathrm{C}$ on the extracts using a high-affinity RAP1-binding site (TEF2) and the binding site for ABF1 (another silencer-binding protein whose activity should be unaffected by these temperature-sensitive mutations). To reduce the effects of general proteolysis, these strains were made protease deficient by disruption of the PEP4 gene (Ammerer et al. 1986). Extracts prepared from rap ${ }^{t s}$ strains maintained at $25^{\circ} \mathrm{C}$ produced a protein-DNA complex with the TEF2 probe that was indistinguishable from that produced in extracts containing wild-type RAP1 (Fig. 9A). In strains carrying the rap1-1 or rap1-4 alleles, RAP1-binding activity, although diminished relative to wild-type strains, remains after prolonged incubation at $37^{\circ} \mathrm{C}$. Strains containing the rap1-2 and rap1-5 alleles have wild-type levels of RAP1 DNA-binding activity under these culture conditions. Although these extracts were prepared from cells maintained at $37^{\circ} \mathrm{C}$, the observed levels of RAP1 DNA-binding activity may be the consequence of renaturation during the course of the binding assay, which was done at $20^{\circ} \mathrm{C}$. To determine whether the temperature-sensitive extracts were capable of binding at nonpermissive temperatures, RAPl-binding activity was assessed at $37^{\circ} \mathrm{C}$. The RAPl-binding activity in all of the rap ${ }^{t s}$, but not wild-type RAP1 strains, is heat labile: Binding reactions performed at $37^{\circ} \mathrm{C}$ do not produce RAP1-DNA complexes, whereas the binding activity of ABF1 in the same extracts is unaffected (Fig. 9B). The loss of RAP1-Binding activity in extracts from rap ${ }^{t s}$ strains does not appear to be the consequence of proteolysis during the binding reaction, as a RAP1 antiserum detects equivalent amounts of full-length protein in Western blots of extracts incubated at $25^{\circ} \mathrm{C}$ or $37^{\circ} \mathrm{C}$ (data not shown).

\section{Discussion}

The importance of RAP1 to MAT $\alpha$ expression was anticipated from previous studies in which the deletion of a small region of the $M A T \alpha$ promoter (containing a RAP1binding site) was shown to abolish transcription and cause $\alpha$ cells to mate inappropriately, becoming a-like "fakers" (Siliciano and Tatchell 1984). More recent stud- 
A

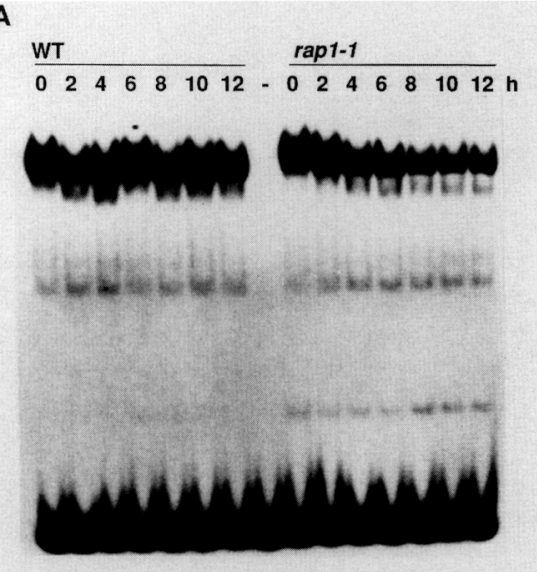

B
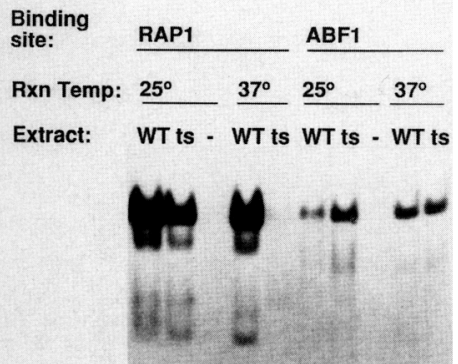

Figure 9. RAP1 DNA-binding activity is heat labile in rap $^{t s}$ strains. $(A)$ Gel mobility-shift assay of RAP1 DNA-binding activity using a high-affinity RAP1-binding site (TEF2). Extracts from wild-type (YDS560) and rap1-1 (YDS561) strains were prepared from continuous cultures following a temperature shift from $25^{\circ} \mathrm{C}$ to $37^{\circ} \mathrm{C}$. Lane designations indicate 2 -hr intervals after temperature shift $;(-)$ a control reaction in which no extract was added. (B) Gel mobility-shift assay of RAP1 and ABF1 DNA-binding activities in extracts prepared from wild-type (YDS560) or rap11 (YDS561) strains maintained at $37^{\circ} \mathrm{C}$ for $12 \mathrm{hr}$. Extracts were incubated in binding assays at $25^{\circ} \mathrm{C}$ or $37^{\circ} \mathrm{C}$, as indicated; $(-)$ a control reaction in which no extract was added. ies in which point mutations were introduced into the RAP1-binding site at MAT $\alpha$ have revealed similar mating and transcriptional defects (Giesman et al. 1991). We have presented two types of experiments that, together, strongly suggest that the RAP1 protein mediates tran-

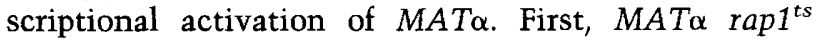
strains fail to produce an $\alpha$-factor halo and inappropriately express two a-specific gene products, a-factor and barrier, a phenotype characteristic of mat $\alpha 1$ mat $\alpha 2$ double mutants. Additionally, in the strongest rap $1^{\text {ts }} \mathrm{mu}$ tants, a significant reduction in the steady-state levels of $M A T \alpha 1$ and MAT $\alpha 2$ transcripts can be observed. Furthermore, the loss of RAP1 in strains carrying only a plasmid-borne copy of the gene leads to a-like mating in $M A T \alpha$ cells, again a property of cells unable to express the $M A T \alpha$ genes. In a second set of experiments we have shown that the $\alpha$-specific defects resulting from the loss of RAPl activity can be overcome by replacing the RAP1-binding site at MAT $\alpha$ with a heterologous UAS element, the GAL4 activator-binding site. This rescue by GAL4 is not an indirect effect owing to overexpression of the MAT $\alpha$ genes, as Northern analysis has shown that the steady-state mRNA levels of both $\alpha 1$ and $\alpha 2$ are similar to those produced from the wild-type MAT $\alpha$ promoter (Fig. 7B). These experiments indicate that the altered mating phenotypes resulting from diminished RAP1 activity are a consequence of reduced transcription at the MAT $\alpha$ locus and support the idea that RAP1 protein functions at the $M A T \alpha$ promoter to activate transcription.

A decrease in the steady-state levels of MAT 1 and MATa2 mRNAs could account for the defect in $\alpha$-specific functions observed in $\operatorname{rap}^{t s}$ strains. However, we note that this decrease is not always detected in RNAs isolated from rap1-1 or rap1-4 strains and is difficult to observe in the rap1-2 and rap1-5 strains. Furthermore, the levels of $M F \alpha 1$ transcript decrease before there is a detectable drop in the transcript levels of MAT 1 la known activator of $M F \alpha 1$ ). One explanation for this observation is that a small decrease in $M A T \alpha$ mRNA levels can result in a dramatic reduction in $M F \alpha 1$ transcript levels. Consistent with this explanation, Giesman et al. (1991) have shown that RAP1-binding site mutations at $M A T \alpha$ that result in only a partial decrease in $M A T \alpha$ steady-state mRNA levels can abolish $\alpha$-factor production and lead to inappropriate expression of a-specific genes. It is also possible that alterations in transcription start sites or mRNA transport, which are not detected by Northern blot analysis, occur after temperature shift in rap $1^{\text {ts }}$ strains and further diminish the pool of functional MAT $\alpha 1$ messages. We consider it unlikely that RAP1 is directly involved in $M F \alpha 1$ expression, as there are no known RAP1-binding sites in the $M F \alpha 1$ promoter or in the promoter of $M C M 1$, another gene required for $M F \alpha 1$ expression. Moreover, the restoration of $M F \alpha 1$ function by altering only the $M A T \alpha$ promoter $\left(\mathrm{UAS}_{\mathrm{Gal}}-M A T \alpha\right)$ indicates that the phenotypes observed in the rap ${ }^{t s} \mathrm{mu}^{-}$ tants result from a defect in transcription at MAT $\alpha$. Finally, we cannot exclude the possibility that $M A T \alpha$ transcription is deficient in the rap ${ }^{t s}$ strains, for example, during a critical period in the cell cycle required for $\alpha 1$ and $\alpha 2$ function. It is not difficult to imagine how a small drop in $M A T \alpha 2$ transcription in an individual cell could lead to a change in cell phenotype. The half-life of $\alpha 2$ protein is $<5 \mathrm{~min}$ (Hochstrasser and Varshavsky 1990), so this protein is likely to be rapidly depleted from the cell under conditions where MAT $\alpha$ expression is not optimal. It is worth noting that the normal process of mating-type switching in homothalic strains also leads to a change in cell type in the course of a single cell cycle.

The relationship between phenotype and mRNA levels that we observe at MAT $\alpha$ may have important implications for understanding the cause of death of the rap $1^{t s}$ mutants. We have failed to detect significant temperature-dependent changes in the transcript levels of other genes (RP73, RNR2, PYK1, LSR, and BCY1; data not shown) that contain RAP1-binding sites in their promoter regions. Given that RAP1 is a transcriptional activator at $M A T \alpha$, we think it is likely that it has a similar function at these other genes, particularly in cases where promoter deletion analyses have shown that a RAP1binding site is a UAS element. As RAP1 becomes limit- 
ing in the temperature-sensitive strains following a temperature shift, we imagine that a complex series of events ensues, considering the large number of genes that may be activated by RAP1. It is possible that the function of some essential genes becomes limiting shortly after the temperature shift, for example, due to a stronger dependence on RAPl for activation, weaker upstream binding sites for the protein, a requirement of full transcription for activity, or a combination of these and other factors. In this case, death may occur before the steady-state mRNA levels of many RAPl-activated genes are affected. As is the case with $M A T \alpha$, a sensitive biological assay may be the most effective way of assessing the effect of RAPl on the transcription of a particular gene. Finally, we have observed that the poly $\left(\mathrm{C}_{1-3} \mathrm{~A}\right)$ tracts at telomeres slowly become shorter at semipermissive temperatures for all of the rap $1^{\text {ts }}$ alleles (Lustig et al. 1990). Therefore, it is possible that some aspect of chromosome stability (perhaps related to telomere function) is significantly perturbed at the nonpermissive temperature in these mutants and ultimately results in lethality.

The contribution of RAP1 to repression of the silent mating-type loci was suggested by previous studies in which deletions of the RAP1-binding site at $H M R$ were shown to result in partial derepression (Brand et al. 1987; Shore and Nasmyth 1987; Kimmerly et al. 1988). One of the rap ${ }^{t s}$ alleles (rap1-5), in combination with a deletion of a silencer regulatory element (either A or B), resulted in a temperature-dependent derepression of the HMR locus. The level of derepression, although not as dramatic as that observed for a complete silencer deletion, may in part reflect the extent of derepression attainable in a population of cells facing impending death. The allele specificity of the derepression we observe suggests that silencing and activation may be two mechanistically different and separable functions of RAP1. For example, the rap1-2 and rap1-5 alleles have similar growth characteristics, yet differ in their effects at $H M R$. Likewise, the rap 1-4 and rap1-1 alleles affect growth more severely than does the rap1-5 allele, yet display little or no derepression of HMR. The separation of essential and silencing functions of RAP1 has been demonstrated directly by the isolation of rap1 point mutants defective in silencing that grow at wild-type rates and display no defect in $M A T \alpha$ activation (L. Sussel and D. Shore, in prep.). All of these silencer-specific rap1 mutants map to the carboxyterminal 100 amino acids of RAP1. It may be noteworthy that the temperature-sensitive mutant that most severely affects silencing (rap1-5) maps closer to the carboxy-terminal end of the RAP1 protein than the other temperature-sensitive alleles.

We have not examined the effect of the rap $1^{\text {ts }}$ mutants on silencing at the HML locus. The cis requirements for silencing at $H M L$ differ from those at $H M R$ in that sequences flanking either side of the locus (HMLE and $H M L I$; left and right flanking, respectively) are by themselves sufficient for silencing (Mahoney and Broach 1989|. In addition, the $H M L I$ silencer, unlike either $H M L E$ or the $H M R$ silencer, appears to lack a strong
RAP1-binding site (Shore et al. 1987; Buchman et al. 1988a). Therefore, one might predict, that the rap $1^{\text {ts }} \mathrm{mu}$ tants would only affect silencing at $H M L$ in the absence of the $H M L I$ silencer.

There is a striking parallel between the role of RAP1 in mating-type gene expression and the role of the MCM1 (PRTF/GRM) protein in the regulation of downstream aand $\alpha$-specific genes (for review, see Herskowitz 1989; Sprague 1990). In a cells the MCM1 protein binds upstream of a-specific genes and activates their transcription, whereas in $\alpha$ cells MCM1 functions both as a corepressor (together with $\alpha 2$ ) to block the expression of aspecific genes and as a coactivator (with $\alpha 1$ protein) to stimulate the transcription of $\alpha$-specific genes (Bender and Sprague 1987; Keleher et al. 1988; Tan et al. 1988; Passmore et al. 1989/. The ability of sequence-specific DNA-binding proteins to function as both repressors and activators of transcription through combinatorial interactions with other regulatory proteins may be a general theme in eukaryotic transcriptional regulation (Diamond et al. 1990). In the case of MCM1, the factors that determine whether it acts positively or negatively appear to be clearly defined: the presence or absence of the interacting $\alpha 1$ and $\alpha 2$ proteins and sequences flanking the MCM1-binding sites that are recognized by these proteins. The factors that influence RAP1 function are less clearly defined. Although the SIR gene products are required in trans for silencing and the GAL11/SPT13 gene product appears to be required for activation of $M A T \alpha$ (Fassler and Winston 1989; Nishizawa et al. 1990), it is still unclear whether any of these proteins interact directly with RAP1 and/or flanking DNA regulatory sequences.

\section{Materials and methods}

Yeast media and methods

Strains were maintained at $25^{\circ} \mathrm{C}$ (fully permissive conditions) in rich medium (YEPD) or on minimal media supplemented with the appropriate amino acids, as described in Sherman et al. (1983) (see Table 2). For the analysis of temperature-sensitive strains, log-phase cultures growing at $25^{\circ} \mathrm{C}$ were shifted to $37^{\circ} \mathrm{C}$ (fully restrictive conditions) or $30-33^{\circ} \mathrm{C}$ (semirestrictive conditions). The temperature-sensitive phenotype was routinely checked before and after time course experiments to ensure that revertants had not accumulated. Yeast strains were transformed by the spheroplast method (Beggs 1978) or by the LiOAc method (Ito et al. 1983), as indicated.

Quantitative mating analysis was performed according to Sprague and Herskowitz (1981). Values of relative mating efficiencies were normalized to the number of viable cells plated. Halo assays were done as described in Julius et al. (1983). All strains tested in halo assays were taken from freshly streaked YEPD plates. Colonies were patched on YEPD plates to which a dilute lawn of responder cells (either strain RC634 or XBH8-2c) had been spread. Plates were then incubated at $25^{\circ} \mathrm{C}$ or $30-33^{\circ} \mathrm{C}$ to examine temperature-dependent effects.

Generation of rap $^{\text {ts }}$ strains

Plasmid D130, which contains CEN IV, TRP1, and the wildtype $R A P 1$ gene, was mutagenized in vitro by incubating $30 \mu \mathrm{g}$ 
Table 2. Strains

YDS 2: HML $\alpha$ MATa HMRa ade2-1 can1-100 his3-11,-15 leu2-3,-112 trp1-1 ura3-1

YDS 3: HML $\alpha$ MAT $\alpha$ HMRa ade2-1 can1-100 his3-11,-15 leu2-3,-112 trp1-1 ura3-1

YDS31: MATa his1

YDS32: MATa his1

YDS36: YDS3 $h m r \Delta A$ (silencer deletion 352-358; Brand et al. 1987).

YDS37: YDS3 hmr $\Delta B$ (silencer deletion 300-256; Brand et al. 1987)

YDS39: YDS3 $h m r \Delta E$ (silencer deletion 331-324; Brand et al. 1987)

YDS203-2d: YDS3 rap1 :: LEU2, pD145(YCP50, RAP1, URA3, sup4-o)

YDS203-6b: YDS2 rap1 :: LEU2, pD145(YCP50, RAP1, URA3, sup4-ol

YDS338: YDS3 $h m r \Delta E B$ (silencer deletions 331-324 and 274-256; Brand et al. 1987)

YDS406: YDS3 rap1-1

YDS407: YDS2 rap1-1

YDS408: YDS2 rap1-2

YDS409: YDS3 rap1-2

YDS410: YDS3 rap1-5

YDS411: YDS2 rap1-5

YDS412: YDS2 rap1-4

YDS413: YDS3 rap1-4

YDS438: YDS3 $\Delta$ gal80

YDS439: YDS406 $\Delta$ gal80

YDS444: YDS438 UAS $_{\mathrm{Gal}}-M A T \alpha$

YDS447: YDS439 $\mathrm{UAS}_{\mathrm{Gal}}-M A T \alpha$

YDS539: YDS3 bar1 :: LEU2

YDS540: YDS406 bar1 :: LEU2

YDS544: YDS406 hmr $\Delta A$

YDS545: YDS406 $h m r \Delta B$

YDS546: YDS409 hmr $\Delta A$

YDS547: YDS409 $h m r \Delta B$

YDS548: YDS413 $h m r \Delta A$

YDS549: YDS413 $h m r \Delta B$

YDS550: YDS410 $h m r \Delta A$

YDS551: YDS410 hmr $\Delta B$

YDS558: YDS406 $\mathrm{UAS}_{\mathrm{Gal}}-M A T$

YDS560: YDS3 pep4:: URA3

YDS561: YDS406 pep4 :: URA3

YDS562: YDS409 pep4 :: URA3

YDS563: YDS410 pep4 :: URA3

YDS564: YDS413 pep4 :: URA3

RC634: MATa sst1-3 ade2 his6 met1 ura1 rmel (from R. Chan)

XBH8-2c: MATa sst2-4 cryl ${ }^{r}$ his6 ura1 met1 (from L. Blair)

of plasmid DNA in a solution of $1 \mathrm{M}$ hydroxylamine/ $0.45 \mathrm{~N}$ $\mathrm{NaOH}$ for $20 \mathrm{hr}$ at $37^{\circ} \mathrm{C}$ (Rose and Fink 1987). The mutagenesis reaction was quenched by the addition of $\mathrm{NaCl}$ to a concentration of $0.1 \mathrm{M}$ and bovine serum albumin to $0.1 \mu \mathrm{g} / \mathrm{ml}$. The solution was precipitated twice with ethanol, resuspended in 10 $\mathrm{mM}$ Tris- $\mathrm{HCl}$ ( $\mathrm{pH} 8.0$ )/1 mM EDTA, and used directly to transform strain YDS203, a yeast strain carrying a deletion of the chromosomal RAP1 gene and a plasmid-borne copy of the wildtype gene, using the spheroplast transformation procedure. Transformants were then grown selectively for both plasmids at $37^{\circ} \mathrm{C}$ to eliminate cells that had acquired a chromosomal temperature-sensitive-lethal mutation during transformation. Col- onies were then replica-plated to media containing canavanine, an arginine analog, resulting in loss of the plasmid carrying the wild-type RAP1 gene. Transformants (now carrying only the mutagenized plasmid) were screened for conditional growth (lethality at $37^{\circ} \mathrm{C}$ ). Using this screen, four colonies, identified from a population of 5500 independent transformants, contained plasmids to which the temperature-sensitive phenotype was linked. Confirmation that the mutations were plasmid linked was obtained by isolating the plasmids and using them to transform the original strain, YDS203. All of the transformants were temperature sensitive. Additionally, the temperature-sensitive phenotype always segregated with the plasmid in appropriate test crosses. Plasmids from the four temperature-sensitive strains were digested with EcoRI to recover a $4.2-\mathrm{kb}$ fragment containing the mutant rap1 alleles. These fragments were subcloned into a pUC-based vector that also contained the URA3 selectable marker and used to replace the wild-type $R A P 1$ locus by transformation (Ito et al. 1983) and subsequent growth on minimal plates containing 5-fluoro-orotic acid (Boeke et al. 1984). Colonies that were temperature sensitive and Ura ${ }^{-}$were analyzed by Southern blotting to confirm the expected structure of the locus. Temperature-sensitive colonies were analyzed further by genetic complementation to confirm the integration of the rap $1^{\text {ts }}$ alleles; transformation with a plasmid containing the wild-type RAP1 gene and crosses to an isogenic strain containing a wild-type RAP1 gene complemented the growth defect at $37^{\circ} \mathrm{C}$.

\section{Mapping and sequencing of $\mathrm{rapl}^{\mathrm{ts}}$ alleles}

The location of each mutation was determined by complementation of the temperature-sensitive lethality with hybrid RAP1 genes constructed by interchanging fragments of the mutant allele with homologous fragments from the wild-type RAP1 gene. Fragments containing the entire coding region of the mutant rap1 alleles (from the PstI site at nucleotide position 853 to the $X b a I$ site at position 3670 ) were subcloned into pRS315, a $C E N$ vector that contains the LEU2 selectable marker (Sikorski and Hieter 1989). These plasmids were then digested with PstI and SphI or PstI and BgIII. Vector fragments isolated from these digests, and now lacking the respective 1507- or 2011-bp fragments from the rap $1^{\text {ts }}$-coding region, were then ligated with the corresponding fragments isolated from digestion of the wildtype RAP1 gene. Plasmids containing the hybrid genes were then introduced into the temperature-sensitive strains (YDS406, 409, 410,413) by transformation, and growth at $37^{\circ} \mathrm{C}$ was assessed. Complementation of the temperature-sensitive phenotype, indicated by growth at $37^{\circ} \mathrm{C}$, correlated with a particular wild-type fragment for each rap1 allele. Smaller fragments of the wild-type RAP1 gene (generated from the HindIII sites at positions 1843 and 2837) were used to further define the region complementing the temperature-sensitive phenotype to $\sim 500 \mathrm{bp}$. The corresponding fragments obtained from the mutant alleles were then subcloned into the $M 13$ vectors $\mathrm{mp} 18$ and mp19 and sequenced using the Sanger dideoxynucleotide method (Bankier et al. 1987). Mutations were confirmed by sequencing both strands of the appropriate fragment.

\section{Construction of MAT $\alpha$ UAS replacement}

A 4-kb fragment containing the $M A T \alpha$ gene, deleted in the promoter from base pair 1602 to 1618 , was removed by digestion with HindIII from a YRP7-based plasmid provided by K. Tatchell (an XhoI linker had been inserted at the site of the deletion) and inserted at the HindIII site in pIC20 to form plasmid D1446. 
This plasmid was then digested with XhoI, treated with calf alkaline phosphatase, and ligated to a 22-bp oligonucleotide (5'-TCGACGGAAGACTCTCCTCCGC-3' and its complement 5'-TCGAGCGGAGGAGAGTCTTCCG-3') containing a GAL4binding site to form $\mathrm{UAS}_{\mathrm{Gal}}-\mathrm{MAT} \alpha$ in plasmid D1452. The 4-kb $\mathrm{UAS}_{\mathrm{Gal}}-\mathrm{MAT} \alpha$ fragment from DI452 was isolated after digestion with HindIII and inserted into pRS306, a integrating vector that also contains the yeast $U R A 3$ gene. This plasmid was used to transform the rap ${ }^{t s}$ strains. Stable $\mathrm{Ura}^{+}$prototrophs were analyzed by Southern blotting to verify that the integration occurred at the $M A T$ locus. Thus, these transformants contain a duplication at the MAT locus in which the $\mathrm{UAS}_{\mathrm{Gal}}-M A T \alpha$ construct is adjacent to the endogenous $M A T \alpha$ locus. Transcription of the $\mathrm{UAS}_{\mathrm{Ga}}-M A T \alpha$ construct is constitutive in strains that contain a deletion of the GAL80 locus (YDS444, YDS447) and repressed in glucose-grown strains that contain a wild-type GAL80 gene (YDS558; see Fig. 6). Strains that express the $\mathrm{UAS}_{\mathrm{Ga}}-M A T \alpha$ construct produce wild-type levels of $M A T \alpha 1$ and $M A T \alpha 2$ transcripts at $25^{\circ} \mathrm{C}$ and at $33^{\circ} \mathrm{C}$ as determined by Northern blots.

\section{Isolation and analysis of RNA}

RNAs were isolated from aliquots of log-phase cultures maintained at $25^{\circ} \mathrm{C}, 30^{\circ} \mathrm{C}, 33^{\circ} \mathrm{C}$, or $37^{\circ} \mathrm{C}$ for various times by breaking cells with a vortex blender with glass beads and with phenol and chloroform (Kurtz and Lindquist 1984). RNAs were precipitated in ethanol and analyzed by Northern blotting or with $\mathrm{Sl} \mathrm{nu-}$ clease after hybridization with prime-cut probes for the $M A T \alpha 1$ and SIR 3 transcripts, as described (Miller 1984). Northern blots were prepared after electrophoretic separation of $20 \mu \mathrm{g}$ of total RNA for each time point on $1.4 \%$ agarose-formaldehyde gels. Filters were reprobed after boiling twice in $0.1 \times$ SSC for $5 \mathrm{~min}$.

\section{Gel mobility-shift assay}

Extracts were prepared from strains grown in rich media at $25^{\circ} \mathrm{C}$ or at various times after a shift to $37^{\circ} \mathrm{C}$. Cells were collected in Eppendorf tubes, washed in sterile water, and resuspended in breakage buffer $[0.2 \mathrm{M}$ Tris- $\mathrm{HCl}(\mathrm{pH} 8), 10 \mathrm{~mm} \mathrm{MgCl} 2,1 \mathrm{~mm}$ dithiothreitol, $10 \%$ glycerol, $1 \mathrm{~mm}$ PMSF, $20 \mu \mathrm{g} / \mathrm{ml}$ pepstatin A] with $\sim 0.2 \mathrm{~g}$ of glass beads $(0.5 \mathrm{~mm})$. Cells were broken by vortexing at maximum speed for four 1-min bursts interspersed with incubation on ice. After centrifugation in a microfuge for $15 \mathrm{~min}$, supernatants were removed and the protein concentrations were determined by using the Bio-Rad assay. Gel mobilityshift assays were performed as described (Shore and Nasmyth 1987; Shore et al. 1987) by using $2 \mu \mathrm{g}$ of cell extract per reaction and probes (labeled with $\left[\alpha{ }^{-32}\right.$ P]dATP) containing RAP1- (TEF2) or ABF1-binding sites. Note that the RAPl-binding sites at TEF2 and $M A T \alpha$ are nearly identical matches to the consensus-binding site (see Buchman et al. 1988a). These sites have binding affinities for RAPl that are similar, and these sites compete similarly for RAP1 binding.

\section{Acknowledgments}

We thank Aaron Mitchell for many fruitful discussions and for comments on the manuscript; Mary Ann Osley and Art Lustig for comments on the manuscript; Janet Schultz for guidance with halo assays and for comments on the manuscript; Lori Sussel for comments and assistance with the preparation of figures; Dina Balderes for assistance with DNA sequence analysis; Donnamarie Giesman and Kelly Tatchell for communicating results prior to publication; George Sprague, Kelly Tatchell,
Manny Ares, John Warner, Holly Hurd, Brian Gallay, and Kim Huang for strains and plasmids. This work was supported by grants from the National Institutes of Health (GM40094), Searle Scholar's Program-Chicago Community Trust, the Irma T. Hirschl Caritable Trust, and the American Cancer Society (JFRA-231) to D.S., and by a fellowship from the Jane Coffin Childs Memorial Fund for Cancer Research (to S.K.).

The publication costs of this article were defrayed in part by payment of page charges. This article must therefore be hereby marked "advertisement" in accordance with 18 USC section 1734 solely to indicate this fact.

\section{References}

Abraham, J., K.A. Nasmyth, J.N. Strathern, A.J.S. Klar, and J.B. Hicks. 1984. Regulation of mating-type information in yeast. I. Mol. Biol. 176: 307-331.

Ammerer, G., C.P. Hunter, J.H. Rothman, G.C. Saari, L.A. Valls, and T.H. Stevens. 1986. PEP4 gene of Saccharomyces cerevisiae encodes proteinase $A$, a vacuolar enzyme required for processing of vacuolar precursors. Mol. Cell. Biol. 6: 24902499.

Bankier, A.T., K.M. Weston, and B.G. Barrell. 1987. Random cloning and sequencing by the M13/dideoxynucleotide chain termination method. Methods Enzymol. 155: 51-92.

Beggs, J.D. 1978. Transformation of yeast by a replicating hybrid plasmid. Nature 285: 185-187.

Bender, A. and G.F. Sprague, Jr. 1987. MAT $\alpha 1$ protein, a yeast transcription activator, binds synergistically with a second protein to a set of cell-type-specific genes. Cell 50: 681-691.

Berman, J., C.Y. Tachibana, and B.-K. Tye. 1986. Identification of a telomere-binding activity from yeast. Proc. Natl. Acad. Sci. 83: 3713-3717.

Boeke, J.D., F. LaCroute, and G.R. Fink. 1984. A positive selection for mutants lacking orotidine-5'-phosphate decarboxylase activity in yeast: 5-fluoro-orotic acid resistance. Mol. Gen. Genet. 197: 345-346.

Boeke, J.D., J. Trueheart, G. Natsoulis, and G.R. Fink. 1987. 5-Fluoro-orotic acid as a selective agent in yeast molecular genetics. Methods Enzymol. 154: 164-175

Brake, A., C. Brenner, R. Najarian, P. Laybourn, and J. Merryweather. 1985. Structure of genes encoding precursors of the yeast peptide mating pheromone a-factor. In Transport and secretion of proteins, pp. 103-108. Cold Spring Harbor Laboratory, Cold Spring Harbor, New York.

Brand, A.H., G. Micklem, and K. Nasmyth. 1987. A yeast silencer contains sequences that can promote autonomous plasmid replication and transcriptional activation. Cell 51: 709-721.

Brand, A.H., L. Breeden, J. Abraham, R. Sternglanz, and K. Nasmyth. 1985. Characterization of a "silencer" in yeast: A DNA sequence with properties opposite to those of a transcriptional enhancer. Cell 41: 41-48.

Buchman, A.R., W.J. Kimmerly, J. Rine, and R.D. Kornberg. 1988a. Two DNA-binding factors recognize specific sequences at silencers, upstream activating sequences, autonomously replicating sequences, and telomeres in Saccharomyces cerevisiae. Mol Cell. Biol. 8: 210-225.

Buchman, A.R., N.F. Lue, and R.D. Kornberg. 1988b. Connections between transcriptional activators, silencers, and telomeres as revealed by functional analysis of a yeast DNAbinding protein. Mol. Cell. Biol. 8: 5086-5099.

Capieaux, E., M.-L. Vignais, A. Sentenac, and A. Goffeau. 1989. The yeast $\mathrm{H}^{+}$-ATPase gene is controlled by the promoter binding factor TUF. I. Biol. Chem. 264: 7437-7446. 
Chambers, A., C. Stanway, A.J. Kingsman, and S.M. Kingsman. 1988. The UAS of the yeast PGK gene is composed of multiple functional elements. Nucleic Acids Res. 16: 82458260.

Chan, R.K. 1977. Recovery of Saccharomyces mating type a cells from G1 arrest by $\alpha$ factor. J. Bacteriol. 130: 766-774.

Diamond, M.I., J.N. Miner, S.K. Yoshinaga, and K.R. Yamamoto. 1990. Transcription factor interactions: Selectors of positive or negative regulation from a single DNA element. Science 249: 1266-1272.

Diffley, J.F.X. and B. Stillman. 1988. Purification of a yeast protein that binds to origins of DNA replication and a transcriptional silencer. Proc. Natl. Acad. Sci. 85: 2120-2124.

Dunn, B. 1989. "Telomeres of Saccharomyces cerevisiae." Ph.D. thesis, Harvard University, Cambridge, Massachusetts.

Elledge, S.J. and R.W. Davis. 1989. Identification of the DNA damage-responsive element of RNR2 and evidence that four distinct cellular factors bind it. Mol. Cell. Biol. 9: 53735386.

Fassler, J.S. and F. Winston. 1989. The Saccharomyces cerevisiae SPT13/GAL11 gene has both positive and negative regulatory roles in transcription. Mol. Cell. Biol. 9: 5602-5609.

Giesman, D., L. Best, and K. Tatchell. 1991. Role of RAP1 in the regulation of the MAT $\alpha$ locus. Mol. Cell. Biol. 11: 10691079.

Henry, Y.A.L., A. Chambers, J. Tsang, A.J. Kingsman, and S.M. Kingsman. 1990. Characterisation of the DNA binding domain of the yeast RAPl protein. Nucleic Acids Res. 18: $2617-2623$.

Herskowitz, I. 1989. A regulatory hierarchy for cell specialization in yeast. Nature 342: 749-757.

Hochstrasser, M. and A. Varshavsky. 1990. In vivo degradation of a transcriptional regulator: The yeast $\alpha 2$ repressor. Cell 61: 697-708.

Huet, J., P. Cottrelle, M. Cool, M.-L. Vignais, D. Theile, C. Marck, J.-M. Buhler, A. Sentenac, and P. Fromageot. 1985. A general upstream binding factor for genes of the yeast translational apparatus. EMBO J. 4: 3539-3547.

Hurd, H.K. and J.W. Roberts. 1989. Upstream regulatory sequence of the yeast $R N R 2$ gene include a repression sequence and an activation site that binds the RAPl protein. Mol. Cell. Biol. 9: 5359-5372.

Ito, H., V. Fukuda, D. Murata, and A. Kimura. 1983. Transformation of intact yeast cells treated with alkali cations. $J$. Bacteriol. 153: 163-168.

Johnson, A.D. and I. Herskowitz. 1985. A repressor (MATa2 product) and its operator control expression of a set of celltype-specific genes in yeast. Cell 42: 237-247.

Johnston, S.A., J. M. Salmeron, and S.S. Dincher. 1987. Interaction of positive and negative regulatory proteins in the galactose regulon of yeast. Cell 50: 143-146.

Julius, D., L. Blair, A. Brake, G. Sprague, and J. Thorner. 1983. Yeast $\alpha$ factor is processed from a larger precursor polypeptide: The essential role of a membrane-bound dipeptidyl amino peptidase. Cell 32: 839-852.

Kayne, P.S., U.-J. Kim, M. Han, J.R. Mullen, F. Yoshizaki, and M. Grunstein. 1988. Extremely conserved histone H4 N-terminus is dispensable for growth, but essential for repressing the silent mating type loci in yeast. Cell 55: 27-39.

Keleher, C.A., C. Goute, and A.D. Johnson. 1988. The yeast cell-type-specific repressor $\alpha 2$ acts cooperatively with a noncell-type-specific protein. Cell 53: 927-936.

Kimmerly, W.J., A.R. Buchman, R.D. Kornberg, and J. Rine. 1988. Roles of two DNA-binding factors in replication, segregation and transcriptional repression mediated by a yeast silencer. $E M B O$ I. 7: 2241-2253.

Kurtz, S. and S. Lindquist. 1984. Changing patterns of gene expression during sporulation in yeast. Proc. Natl. Acad. Sci. 81: 7323-7327.

Lue, N.F., D.I. Chasman, A.R. Buchman, and R.D. Kornberg. 1987. Interaction of GAL4 and GAL80 gene regulatory proteins in vitro. Mol. Cell Biol. 7: 3446-3451.

Lustig, A.J., S. Kurtz, and D. Shore. 1990. Involvement of the silencer and UAS binding protein RAP1 in regulation of telomere length. Science 250: 549-553.

Ma, J. and M. Ptashne. 1987. The carboxy-terminal 30 amino acids of GAL4 are recognized by GAL80. Cell 50: 137-142.

Mahoney, D.J. and J.R. Broach. 1989. The HML mating-type cassette of Saccharomyces cerevisiae is regulated by two separate but functionally equivalent silencers. Mol. Cell. Biol. 9: 4621-4630.

Mann, C., J.-M. Buhler, I. Treich, and A. Sentenac. 1987. RPC40, a unique gene for a subunit shared between yeast RNA polymerases A and C. Cell 48: 627-637.

Miller, A.M. 1984. The yeast MATa1 gene contains two introns. EMBO I. 3: 1061-1065.

Miller, A.M. and K.A. Nasmyth. 1984. Role of DNA replication in the repression of silent mating-type loci in yeast. Nature 312: $247-251$.

Mullen, J.R., P.S. 'Kayne, R.P. Moerschell, S. Tsunasawa, M. Gribskov, M. Colavito-Shepanski, M. Grunstein, F. Sherman, and R. Sternglanz. 1989. Identification and characterization of genes and mutants for a $\mathrm{N}$-terminal acetyltransferase from yeast. $E M B O$ I. 8: 2067-2075.

Nasmyth, K. and D. Shore. 1987. Transcriptional regulation in the yeast life cycle. Science 237: 1162-1170.

Nishizawa, M., R. Araki, and Y. Teranishi. 1989. Identification of an upstream activating sequence and an upstream repressible sequence of the pyruvate kinase gene of the yeast Saccharomyces cerevisiae. Mol. Cell. Biol. 9: 442-451.

Nishizawa, M., Y. Suzuki, Y. Nogi, K. Matsumoto, and T. Fukasawa. 1990. Yeast Gall1 protein mediates the transcriptional activation signal of two different transacting factors, Gal4 and general regulatory factor $\mathrm{I} /$ repressor/activator site binding protein 1/translation upstream factor. Proc. Natl. Acad. Sci. 87: 5373-5377.

Passmore, S., R. Elble, and B.-K. Tye. 1989. A protein involved in minichromosome maintenance in yeast binds a transcriptional enhancer conserved in eukaryotes. Genes \& Dev. 3: 921-935.

Pillus, L. and J. Rine. 1989. Epigenetic inheritance of transcriptional states in S. cerevisiae. Cell 59: 637-647.

Rine, J. and I. Herskowitz. 1987. Four genes responsible for a position effect on expression from $H M L$ and $H M R$ in Saccharomyces cerevisiae. Genetics 93: 877-901.

Rose, M.D. and G.R. Fink. 1987. KAR1, a gene required for function of both intranuclear and extranuclear microtubules in yeast. Cell 48: 1047-1060.

Rotenberg, M.O. and J.L. Woolford. (1986). Tripartite upstream promoter element essential for expression of Saccharomyces cerevisiae ribosomal protein genes. Mol. Cell. Biol. 6: 674687.

Sherman, F., G.R. Fink and J.B. Hicks. 1983. Methods in yeast genetics. Cold Spring Harbor Laboratory, Cold Spring Harbor, New York.

Shore, D. and K. Nasmyth. 1987. Purification and cloning of a DNA binding protein from yeast that binds to both silencer and activator elements. Cell 51: 721-732.

Shore, D., D.J. Stillman, A.H. Brand, and K.A. Nasmyth. 1987. Identification of silencer binding proteins from yeast: Possible roles in SIR control and DNA replication. EMBO $J$. 
6: $461-467$.

Sikorski, R. and P. Hieter. 1989. A system of shuttle vectors and yeast host strains designed for efficient manipulation of DNA in Saccharomyces cerevisiae. Genetics 122: 19-27.

Siliciano, P.G. and K. Tatchell. 1984. Transcription and regulatory signals at the mating type locus in yeast. Cell 37: 969978.

Sprague, G.F., Ir. 1990. Combinatorial associations of regulatory proteins and the control of cell type in yeast. Adv. Genet. 27: 33-62.

Sprague, G. and I. Herskowitz. 1981. Control of yeast cell type by the mating type locus I. Identification and control of expression of the a-specific gene BARl. J. Mol. Biol. 153: 305321.

Strathern, J.N., J.B. Hicks, and I. Herskowitz. 1981. Control of cell type in yeast by the mating-type locus: The $\alpha 1-\alpha 2$ hypothesis. J. Mol. Biol. 147: 357-372.

Tan, S., G. Ammerer, and T.J. Richmond. 1988. Interactions of purified transcription factors: Binding of yeast MAT $\alpha 1$ and PRTF to cell type-specific, upstream activating sequences. EMBO \%. 7: 4255-4264.

Tatchell, K., K.A. Nasmyth, B.D. Hall, C. Astell, and M. Smith. 1981. In vitro mutation analysis of the mating type locus in yeast. Cell 27: 25-35.

Whiteway, M., R. Freeman, S. Van Arsdell, J. W. Szostak, and J. Thorner. 1987. The yeast $A R D 1$ gene product is required for repression of cryptic mating-type information at the $H M L$ locus. Mol. Cell. Biol. 7: 3713-3722. 


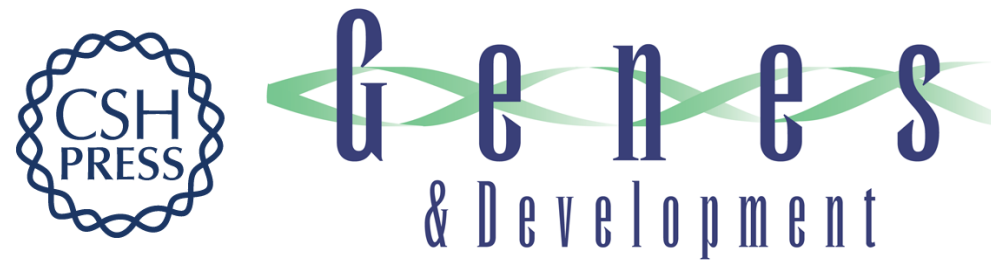

\section{RAP1 protein activates and silences transcription of mating-type genes in yeast.}

S Kurtz and D Shore

Genes Dev. 1991, 5:

Access the most recent version at doi:10.1101/gad.5.4.616

References This article cites 59 articles, 23 of which can be accessed free at:

http://genesdev.cshlp.org/content/5/4/616.full.html\#ref-list-1

License

Email Alerting

Service

Receive free email alerts when new articles cite this article - sign up in the box at the top right corner of the article or click here.

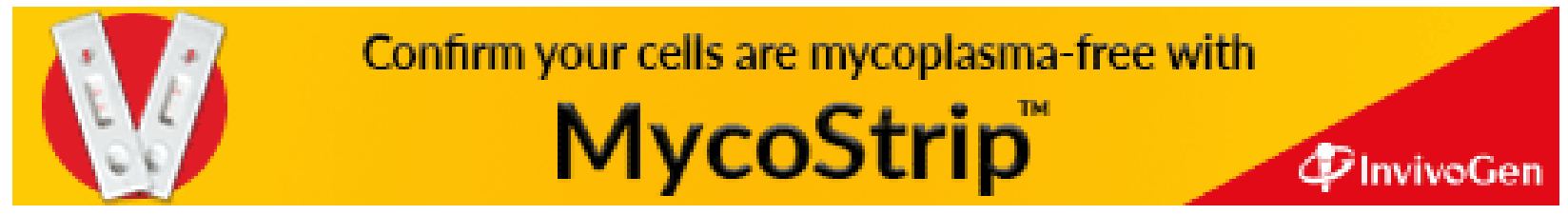

